\title{
Peningkatan Keaktifan dan Prestasi Belajar Mahasiswa melalui Penerapan Metode Pembelajaran Kooperatif tipe STAD (Student Teams Achievement Division)
}

\author{
Hasdinar Umar \\ Departemen Teknik Kelautan, Fakultas Teknik UNHAS \\ hasdinar.umar@gmail com
}

\begin{abstract}
Abstrak
Usaha yang diperlukan untuk mendorong mahasiswa aktif dalam kegiatan perkuliahan tergantung pada dosen yang mengajar. Keaktifan mahasiswa belum berkembang selama proses perkuliahan pada mata kuliah Proses Pantai. Hal tersebut memberi dampak pada prestasi belajar mahasiswa. Hal tersebut menjadi indikator diperlukannya upaya untuk membantu mahasiswa agar dapat memahami mata kuliah Proses Pantai dengan lebih baik sesuai dengan tujuan pembelajaran. Penerapan metode pembelajaran kooperatif tipe STAD lebih mendorong kemandirian, keaktifan dan tanggung jawab dalam diri mahasiswa. Pada metode pembelajaran tersebut mahasiswa lebih banyak berperan selama kegiatan perkuliahan berlangsung, dosen hanya berperan mengarahkan mahasiswa dan memberi masukan pada setiap diskusi kelompok yang dilakukan. Hasil penerapan menunjukkan bahwa kreativitas mahasiswa pada mata kuliah Proses Pantai melalui penerapan metode pembelajaran kooperatif tipe STAD mengalami peningkatan, yang mana ditunjukkan pada persentase kriteria respon mahasiswa sebesar 91,56\% atau respon mahasiswa yang sangat tinggi. Keaktifan mahasiswa pada mata kuliah Proses Pantai melalui penerapan metode kooperatif tipe STAD mengalami peningkatan, ditunjukkan dengan persentase skor keaktifan mahasiswa selama perkuliahan sebesar 97,29\% atau tingkat keaktifan tinggi. Serta prestasi belajar mahasiswa pada mata kuliah Proses Pantai melalui penerapan metode pembelajaran kooperatif tipe STAD mengalami peningkatan, yang mana hal tersebut ditunjukkan pada hasil perbandingan nilai akhir mahasiswa angkatan 2015 (tanpa metode) dan mahasiswa angkatan 2016 (dengan metode).
\end{abstract}

Kata Kunci: Pembelajaran; Keaktifan; Respon; Prestasi; STAD.

\section{Pendahuluan}

Kompetensi utama yang diharapkan pada Kurikulum Departemen Teknik Kelautan adalah mahasiswa mampu menerapkan ilmu pengetahuan dasar keteknikan perancangan dan pembangunan serta pemeliharaan bangunan laut dan pantai, selain itu juga mahasiswa harus mampu menerapkan ilmu pengetahuan terapan dan aplikasi pengembangan teknologi teknik lepas pantai (offshore engineering), teknik pelabuhan (dock and harbor engineering) dan teknik pantai (coastal engineering). Mata kuliah Proses Pantai merupakan salah satu Matakuliah Keahlian Berkarya (MKB) pada Departemen Teknik Kelautan yang dapat memudahkan mahasiswa untuk memperoleh kompetensi tersebut.

Kompetensi utama dari mata kuliah Proses Pantai adalah mahasiswa mampu menerapkan pengetahuan dasar tentang proses yang terjadi di pantai. Kompetensi utama tersebut dapat tercapai jika dilakukan metode pembelajaran yang tepat kepada mahasiswa serta tersedianya bahan ajar yang memadai. Metode pembelajaran kooperatif tipe STAD (Student Team Achievement Division) merupakan salah satu metode yang dapat digunakan untuk meningkatkan keaktifan mahasiswa dan prestasi mahasiswa terhadap suatu mata kuliah. Metode pembelajaran kooperatif tipe STAD adalah metode pembelajaran dimana mahasiswa belajar dalam sistem 
kelompok secara kooperatif, mahasiswa dibentuk berkelompok berdasarkan kemampuan tinggi, sedang dan rendah. Pada metode STAD penghargaan lebih diutamakan pada kerja kelompok daripada kerja perorangan.

\section{Landasan Teori}

\subsection{Metode Pembelajaran Kooperatif}

Pembelajaran kooperatif menggunakan sistem pengelompokan yang terdiri dari empat sampai enam orang dengan kemampuan akademik, jenis kelamin, suku yang heterogen (Sanjaya, 2007). Pada proses pembelajarannya mahasiswa diberi kesempatan bekerja dalam kelompok kecil untukmendiskusikan dan memecahkan masalah. Tugas kelompok dapat memacu para mahasiswa untuk bekerja sama dalam mengintegrasikan pengetahuan baru dengan pengetahuan yang telah dimilikinya.

Untuk penguasaan materi pelajaran setiap mahaasiswa dalam kelompok bertanggung jawab secara bersama dengan cara berdiskusi, saling tukar pendapat, pengetahuan dan pengalaman. Kemampuan atau prestasi setiap anggota kelompok sangat menentukan hasil pencapaian belajar kelompok, untuk itu penguasaan materi pelajaran setiap mahasiswa ditekankan dalam strategi pembelajaran kooperatif. Dengan pembelajaran kooperatif diharapkan mahasiswa dapat mengembangkan semua potensinya secara optimal dengan cara berpikir aktif selama proses belajar berlangsung.

Pengelolaan pembelajaran dengan menggunakan strategi pembelajaran kooperatif mempunyai 3 (tiga) tujuan yang hendak dicapai yaitu:

a. Hasil belajar akademik

Pembelajaran koopertaif bertujuan untuk meningkatkan kinerja mahasiswa dalam tugas akademik. Banyak ahli berpendapat bahwa model koopertaif unggul dalam membantu mahasiswa memahami konsep-konsep sulit.

b. Pengakuan adanya keragaman

Model kooperatif bertujuan agar mahasiswa dapat menerima teman-temannya yang mempunyai berbagai macam perbedaan latar belakang. Perbedaan tersebut antara lain perbedaan suku, agama, kemampuan akademik dan tingkat sosial.

c. Pengembangan keterampilan

Pembelajaran kooperatif bertujuan untuk mengembangkan keterampilan mahasiswa. Keterampilan sosial yang dimaksud adalah berbagi tugas, aktif bertanya, menghargai pendapat orang lain, mau menjelaskan ide atau pendapat dan bekerja dalam kelompok.

\subsection{Pembelajaran Kooperatif Tipe STAD}

Kelompok belajar dalam STAD merupakan kelompok yang terdiri dari empat atau lima mahasiswa yang mewakili heterogenitas dalam ruang kuliah, yang ditinjau dari kinerja, suku dan jenis kelamin. Menurut Nur (2005) STAD terdiri dari lima komponen utama yaitu:

a. Presentasi kelas, pada kegiatan ini mahasiswa harus sungguh-sungguh memperhatikan presentasi dosen di ruang kuliah karena dengan begitu akan membantu mahasiswa dalam mengerjakan kuis dengan baik. Skor yang mereka peroleh nantinya akan menentukan skor timnya. 
Jurnal Tepat (Teknologi Terapan Untuk Pengabdian Masyarakat), Volume 1, Nomor 1, Tahun 2018

b. Kerja tim, setelah dosen mempresentasikan materi, kemudian tim berkumpul untuk mempelajari materi yang sudah diberikan dengan menggunakan lembar kerja. Pada tahap kerja kelompok ini mahasiswa secara bersama mendiskusikan masalah dan membantu antar anggota dalam kelompoknya. Kerja tim yang paling sering dilakukan adalah membetulkan setiap kekeliruan atau miskonsepsi apabila teman sesama tim membuat kesalahan.

c. Kuis, untuk mengetahui sejauh mana keberhasilan mahasiswa memahami materi yang dibahas. Pada saat mengerjakan kuis mahasiswa harus bekerja secara individu sekalipun skor yang ia peroleh nanti dapat digunakan untuk menentukan keberhasilan kelompoknya. Kepada setiap individu, dosen akan memberikan skor yang digunakan untuk menentukan skor bersama bagi setiap kelompok.

d. Skor perbaikan individu, skor yang diperoleh setiap anggota dalam mengerjakan kuis akan berkontribusi pada kelompok mereka dan didasarkan sejauh mana skor mereka telah meningkat dibandingkan skor rata-rata awal yang telah mereka capai sebelumnya. Berdasarkan skor awal setiap individu ditentukan skor peningkatan atau perkembangan. Rata-rata skor peningkatan dari tiap individu dalam suatu kelompok akan digunakan untuk menentukan penghargaan bagi kelompok yang berprestasi.

e. Penghargaan tim, kelompok dapat memperoleh sertifikat atau penghargaan lain apabila skor rata-rata yang didapat melampaui kriteria tertentu. Penghargaan yang diperoleh menunjukkan keberhasilan setiap kelompok dalam menjalin kerjasama antar anggota kelompok. Penghargaan kelompok dilakukan dengan memberikan penghargaan berupa sertifikat atau penghargaan lain atas usaha dan kerja keras yang dilakukan kelompok.

Menurut Nur (2005) ada tiga tingkat penghargaan yang diberikan berdasarkan skor tim rata-rata.

Tabel 1. Kriteria Penghargaan Kelompok (Nur, 2005)

\begin{tabular}{cc}
\hline Kriteria (rata-rata tim) & Penghargaan \\
\hline 15 & Tim baik \\
20 & Tim hebat \\
25 & Tim super \\
\hline
\end{tabular}

\subsection{Keaktifan Mahasiswa}

Aktif menurut kamus besar bahasa Indonesia (2002) berarti giat (bekerja atau berusaha), sedangkan keaktifan berarti sebagai hal atau keadaan dimana mahasiswa dapat aktif. Keaktifan mahasiswa dalam belajar tampak dalam kegiatan berbuat sesuatu untuk memahami materi pelajaran. Menurut Usman (2002), cara yang dapat dilakukan seorang dosen untuk memperbaiki keterlibatan mahasiswa antara lain:

1. Tingkatkan persepsi mahasiswa secara aktif dalam kegiatan belajar mengajar yang membuat respon yang aktif dari mahasiswa.

2. Masa transisi antara kegiatan dalam mengajar hendaknya dilakukan secara cepat dan luwes.

3. Berikan pengajaran yang jelas dan tepat sesuai dengan tujuan mengajar yang akan dicapai.

4. Usahakan agar pengajaran dapat lebih memacu minat mahasiswa.

Menurut Lidgen dalam Usman (2002), terdapat empat jenis interaksi dalam kegiatan belajar mengajar diantaranya sebagai berikut.

1. Komunikasi satu arah, komunikasi yang hanya dilakukan oleh dosen terhadap mahasiswa, sementara mahasiswa hanya pasif sebatas mendengarkan komunikasi dari dosen. 
Jurnal Tepat (Teknologi Terapan Untuk Pengabdian Masyarakat), Volume 1, Nomor 1, Tahun 2018

2. Komunikasi dua arah tanpa interaksi antar mahasiswa, dalam komunikasi ini ada umpan balik buat dosen, namun tidak ada interaksi diantara mahasiswa.

3. Komunikasi dua arah dengan interaksi antar mahasiswa namun belum keseluruhan, komunikasi dari dosen sudah mendapat respon balik dari mahasiswa dan sudah ada interaksi diantara mahasiswa, tetapi belum keseluruhan dari mahasiswa yang melakukan interaksi baik dengan dosen maupun mahasiswa lainnya.

4. Komunikasi dua arah dengan interaksi optimal antara dosen dan mahasiswa dan antar mahasiswa dengan mahasiswa lainnya, komunikasi ini sudah berjalan baik antara dosen dengan mahasiswa maupun antara mahasiswa dengan mahasiswa lainnya. Pada komunikasi ini interaksi yang terjadi sudah optimal selama proses pembelajaran.

Jenis-jenis interaksi pembelajaran yang dijelaskan di atas menujukkan derajat keaktifan mahasiswa. Keaktifan mahasiswa merupakan suatu keadaan dimana mahasiswa berpartisipasi secara aktif dalam pembelajaran. Dalam hal ini keaktifan mahasiswa terlihat pada saat merespon pertanyaan atau perintah dari dosen, mendengarkan dan memperlihatkan penjelasan guru, berani mengemukakan pendapat, dan aktif mengerjakan soal yang diberikan oleh dosen.

\section{Metode Eksperimen}

Penerapan metode uji coba tindakan kelas yang dilakukan secara kolaboratif. Dalam penerapan kolaboratif pihak yang melakukan tindakan adalah dosen itu sendiri sedangkan yang diminta melakukan pengamatan terhadap berlangsungnya proses tindakan adalah pengajar (Arikunto, 2002). Ada beberapa tahapan dalam uji coba tindakan kelas, yaitu:

1. Perencanaan (plan)

2. Tindakan $(a c t)$

3. Pengamatan (observe)

4. Refleksi (reflect)

Penerapan metode ini dilakukan dalam tiga siklus. Siklus yang diberikan apabila kondisi kelas sudah stabil yaitu dimana dosen sudah mampu menguasai keterampilan belajar yang baru dan mahasiswa terbiasa dengan model pembelajaran kooperatif tipe STAD serta data yang ditampilkan di kelas sudah jenuh dalam arti sudah ada peningkatan keaktifan dan prestasi belajar mahasiswa.

\subsection{Tahap Penerapan Siklus I}

1. Perencanaan, pada tahap ini dosen mempersiapkan silabus, rencana pelaksanaan perkuliahan, buku ajar, lembar kerja mahasiswa, lembar observasi kreativitas dan keaktifan mahasiswa, lembar angket respon mahasiswa, lembar observasi pelaksanaan metode pembelajaran kooperatif tipe STAD, dan pedoman wawancara.

2. Tindakan, pelaksanaan tindakan pada siklus I dilakukan dalam 3 kali pertemuan. Tahap tindakan dilakukan oleh dosen dengan menerapkan metode pembelajaran kooperatif tipe STAD. Proses pembelajaran dilakukan sesuai dengan jadwal perkuliahan mata kuliah Proses Pantai. Materi yang diberikan adalah materi tentang Gelombang Pecah. Tindakan-tindakan yang dilakukan pada masing-masing siklus adalah:

a.Pendahuluan

Dosen menyampaikan presentasi kelas dengan memberikan apersepsi dan motivasi kepada mahasiswa dalam mempelajari materi Gelombang Pecah. 


\section{b.Kegiatan inti}

Kegiatan inti yang dilakukan adalah mahasiswa belajar dalam kelompok, dosen memberi penekanan dari hasil diskusi dalam kelompok, mahasiswa mengerjakan kuis secara individu, peningkatan nilai, pemberian penghargaan kelompok.

c.Penutup

Dosen memberikan penghargaan kepada kelompok yang berhasil mencapai kriteria keberhasilan tertentu.

3. Observasi, dilakukan selama proses perkuliahan dengan menggunakan lembar observasi yang telah disiapkan dan mencatat kejadian-kejadian yang tidak terdapat pada lembar observasi dengan membuat lembar catatan lapangan. Hal-hal yang diamati selama proses perkuliahan adalah kegiatan perkuliahan dan aktivitas dosen dan mahasiswa selama pelaksanaan perkuliahan.

4. Refleksi, pada tahap ini peneliti bersama dosen melakukan evaluasi dari pelaksanaan tindakan pada siklus pertama yang dijadikan bahan pertimbangan perencanaan perkuliahan siklus berikutnya.

\subsection{Tahap Penerapan Siklus II dan Siklus III}

Rencana tindakan siklus II dimaksudkan sebagai refleksi dan perbaikan terhadap pelaksanaan pembelajaran pada siklus I. Sedangkan siklus III dimaksudkan sebagai refleksi terhadap pelaksanaan pembelajaran pada siklus II. Tahap tindakan pada siklus II dan siklus III mengikut tahapan tindakan pada siklus I.

\section{Analisis Data}

Analisis data yang digunakan adalah reduksi data yaitu kegiatan pemilihan data, penyederhanaan data serta transformasi data kasar dari catatan lapangan. Analisis data yang dilakukan dalam penerapan adalah sebagai berikut.

1. Analisis data observasi keaktifan mahasiswa

Hasil observasi keaktifan mahasiswa dianalisis dengan berpedoman pada lembar observasi keaktifan mahasiswa. Penilaian dapat dilihat pada hasil skor di lembar observasi yang digunakan. Persentase diperoleh dari skor pada lembar observasi dikualifikasikan untuk menentukan seberapa besar keaktifan mahasiswa dalam mengikuti proses perkuliahan. Hasil observasi dianalisis dengan berpedoman pada kriteria sebagai berikut.

Tabel. 2. Kriteria Keaktifan Mahasiswa

\begin{tabular}{ll}
\hline Persentase & Kriteria \\
\hline $75 \%-100 \%$ & Sangat tinggi \\
$50 \%-75 \%$ & Tinggi \\
$25 \%-49,99 \%$ & Sedang \\
$0 \%-24,99 \%$ & Rendah \\
\hline
\end{tabular}

Dosen menggunakan kriteria tersebut karena dalam lembar observasi terdapat empat kriteria penilaian, sehingga terdapat empat kriteria keaktifan. Cara menghitung persentase keaktifan mahasiswa (Sugiyono, 2001) adalah sebagai berikut. 
Jurnal Tepat (Teknologi Terapan Untuk Pengabdian Masyarakat), Volume 1, Nomor 1, Tahun 2018

$$
\text { persentase keaktifan }=\frac{\text { skore keseluruhan yang diperoleh kelompok }}{\text { jumlah kelompok } \times \text { skore maksimum }} \times 100 \%
$$

2. Analisis angket respon mahasiswa

Analisis respon mahasiswa terhadap penggunaan metode kooperatif tipe STAD untuk mata kuliah Proses Pantai dilakukan dengan menggunakan lembar angket. Angket respon mahasiswa terdiri dari 20 butir pertanyaan dengan rincian 10 pertanyaan positif $(+)$ dan 10 pertanyaan negatif (-). Sistem penskoran angket untuk masing-masing pertanyaan positif (+) adalah 4 untuk jawaban sangat setuju, 3 untuk jawaban setuju, 2 untuk jawaban tidak setuju, dan 1 untuk jawaban sangat tidak setuju. Untuk pertanyaan negatif (-) adalah 1 untuk jawaban sangat setuju, 2 untuk jawaban setuju, 3 untuk jawaban tidak setuju, dan 4 untuk jawaban sangat tidak setuju. Setelah data angket diperoleh maka hasil analisis data angket diklasifikasikan dengan kriteria sebagai berikut:

Tabel 3. Kriteria Respon Siswa

\begin{tabular}{ll}
\hline Persentase & Kriteria \\
\hline $75 \%-100 \%$ & Sangat tinggi \\
$50 \%-74,99 \%$ & Tinggi \\
$25 \%-49,99 \%$ & Sedang \\
$0 \%-24,99 \%$ & Rendah \\
\hline
\end{tabular}

Dosen menggunakan kriteria tersebut karena dalam angket respon terdapat empat pilihan jawaban sehingga terdapat empat kriteria respon. Cara menghitung persentase angket respon (Sugiyono, 2001), adalah sebagai berikut.

persentase angket $=\frac{\text { jumlah skore hasil pengumpulan data }}{\text { jumlah skore jika setiap butir mendapat skor tertinggi }} \times 100 \%$

3. Analisis hasil belajar mahasiswa

Penilaian hasil belajar mahasiswa dianalisis dengan cara membandingkan nilai individu mahasiswa diakhir semester. Nilai yang dibandingkan adalah nilai mahasiswa yang belum menerima perkuliahan dengan metode kooperatif tipe STAD pada mata kuliah Proses Pantai dengan mahasiswa yang telah menerima materi kuliah dengan menggunakan metode tersebut.

\section{Hasil dan Diskusi}

\subsection{Keaktifan Mahasiswa}

Hasil observasi keaktifan mahasiswa dianalisis dengan berpedoman pada lembar observasi keaktifan mahasiswa. Penilaian dapat dilihat pada hasil skor di lembar observasi yang digunakan. Persentase diperoleh dari skor pada lembar observasi dikualifikasikan untuk menentukan seberapa besar keaktifan mahasiswa dalam mengikuti proses perkuliahan. Salah satu kondisi aktifitas mahasiswa pada saat proses perkuliahan ditunjukkan pada Gambar 1. Hasil observasi dianalisis dengan berpedoman pada kriteria sebagai berikut.

Tabel. 4. Kriteria Keaktifan Mahasiswa 


\begin{tabular}{ll}
\hline Persentase & Kriteria \\
\hline $75 \%-100 \%$ & Sangat tinggi \\
$50 \%-75 \%$ & Tinggi \\
$25 \%-49,99 \%$ & Sedang \\
$0 \%-24,99 \%$ & Rendah \\
\hline
\end{tabular}

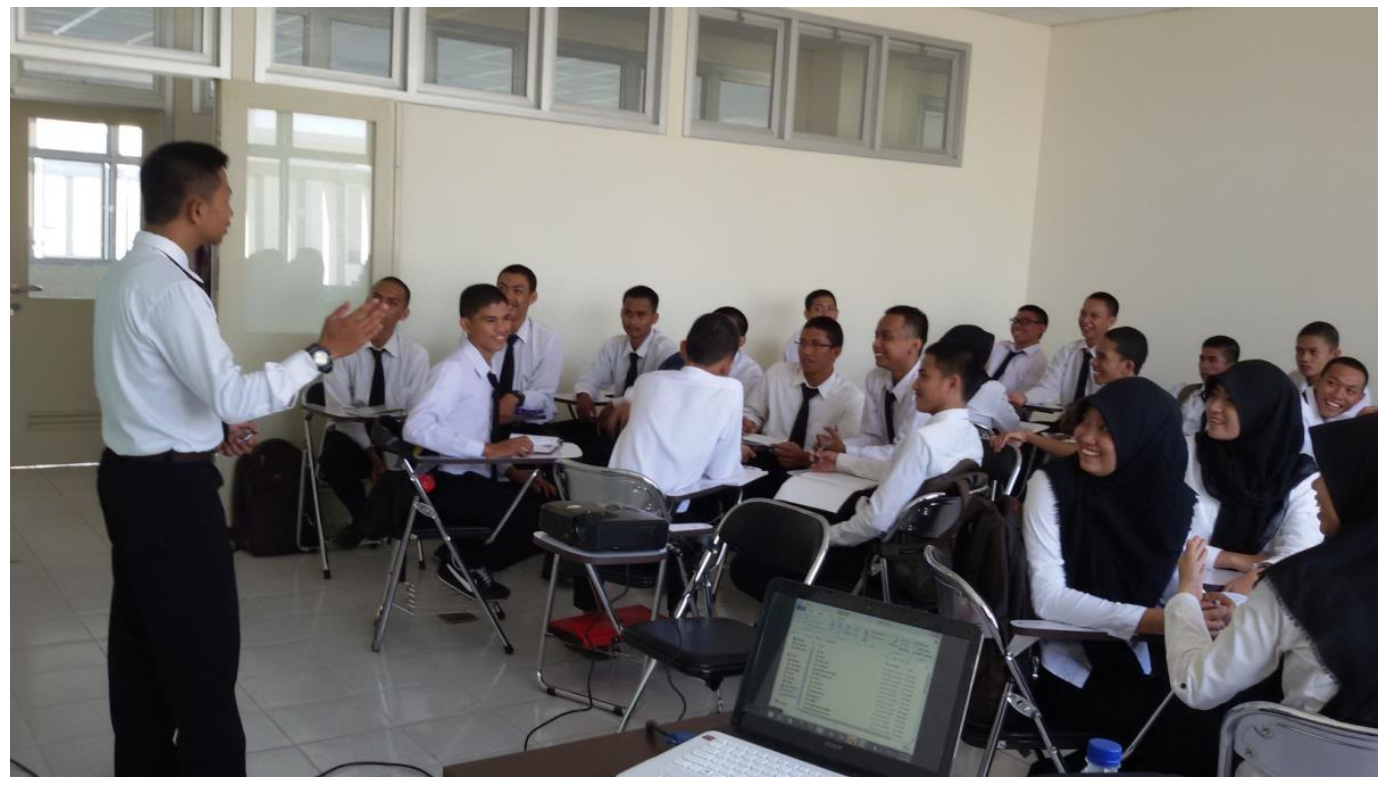

Gambar 1. Aktifitas Mahasiswa pada Proses Perkuliahan

Berdasarkan lembar observasi keaktifan mahasiswa dari masing-masing kelompok, maka diperoleh skor penilaian seperti yang ditunjukkan pada Tabel. 5.

Tabel 5. Skor Penilaian Keaktifan

\begin{tabular}{cc}
\hline Kelompok & Skor \\
\hline 1 & 55 \\
2 & 60 \\
3 & 56 \\
4 & 64 \\
5 & 58 \\
\hline Total & 293 \\
\hline
\end{tabular}

Berdasarkan Tabel 5 di atas maka dapat dianalisis tingkat keaktifan mahasiswa dalam mengikuti perkuliahan Proses Pantai menggunakan persamaan.1.

$$
\begin{aligned}
& \text { persentase keaktifan }=\frac{293}{5 \times 64} \times 100 \% \\
& \text { persentase keaktifan }=91,56 \%
\end{aligned}
$$

Persentase keaktifan sebesar 91,56\% adalah termasuk kriteria keaktifan sangat tinggi. 


\subsection{Respon Mahasiswa}

Analisis respon mahasiswa terhadap penggunaan metode pembelajran kooperatif tipe STAD untuk mata kuliah Proses Pantai dilakukan dengan menggunakan lembar angket. Angket respon yang digunakan adalah angket tertutup dengan alternatif jawaban yaitu: selalu, sering, kadangkadang dan tidak pernah. Berikut kisi-kisi angket respon mahasiswa.

Tabel 6. Kisi-Kisi Angket Respon Mahasiswa

\begin{tabular}{clc}
\hline No & \multicolumn{1}{c}{ Aspek } & Butir \\
\hline 1 & Motivasi dalam mengikuti pelajaran & $1,2,3,14,15,16,20$ \\
2 & Interaksi & 4,7 \\
& a. Interaksi dengan dosen & 6,13 \\
& b. Interaksi denga teman atau mahasiswa lainnya & $5,8,9,10,11$ \\
3 & Kerjasama dengan teman sekelompok & 12 \\
4 & Mengerjakan soal dan tugas & $17,18,19$ \\
& a. Mengerjakan soal dan tugas kelompok & \\
& b. Mengerjakan soal dan tugas individu & \\
\hline
\end{tabular}

Setelah data angket diperoleh maka hasil analisis data angket diklasifikasikan dengan kriteria sebagai berikut:

Tabel 7. Kriteria Respon Siswa

\begin{tabular}{ll}
\hline Persentase & Kriteria \\
\hline $75 \%-100 \%$ & Sangat tinggi \\
$50 \%-74,99 \%$ & Tinggi \\
$25 \%-49,99 \%$ & Sedang \\
$0 \%-24,99 \%$ & Rendah \\
\hline
\end{tabular}

Analisis kriteria respon mahasiswa dalam mengikuti perkuliahan Proses Pantai menggunakan persamaan.2.

$$
\begin{aligned}
\text { persentase respon } & =\frac{2335}{2400} \times 100 \% \\
\text { persentase keaktifan } & =97,29 \%
\end{aligned}
$$

Persentase keaktifan sebesar 97,29\% adalah termasuk kriteria respon yang sangat tinggi.

\section{Hasil Belajar Mahasiswa}

Penilaian hasil belajar mahasiswa dianalisis dengan cara membandingkan nilai individu mahasiswa diakhir semester. Nilai yang dibandingkan adalah nilai mahasiswa angkatan 2012 yang belum menerima perkuliahan dengan metode student facilitator and explaining pada mata kuliah Teknologi Bahan dengan mahasiswa angkatan 2014 yang telah menerima materi kuliah dengan menggunakan metode tersebut. Nilai akhir kedua angkatan tersebut jika dibandingkan maka terlihat peningkatan nilai yang cukup baik. Rekap perbandingan nilai ditunjukkan pada Tabel 8 berikut. 
Jurnal Tepat (Teknologi Terapan Untuk Pengabdian Masyarakat), Volume 1, Nomor 1, Tahun 2018

Tabel 8. Perbandingan Nilai Akhir

\begin{tabular}{|c|c|c|c|c|c|c|c|}
\hline \multicolumn{4}{|c|}{ Angkatan 2016} & \multicolumn{4}{|c|}{ Angkatan 2015} \\
\hline $\mathrm{A}$ & $=$ & 10 & $25,64 \%$ & $\mathrm{~A}$ & $=$ & 11 & $28,21 \%$ \\
\hline A- & $=$ & 5 & $12,82 \%$ & A- & $=$ & 3 & $7,70 \%$ \\
\hline $\mathrm{B}+$ & $=$ & 11 & $28,2 \%$ & $\mathrm{~B}+$ & $=$ & 2 & $5,13 \%$ \\
\hline $\mathrm{B}$ & $=$ & 10 & $25,64 \%$ & B & $=$ & 2 & $5,13 \%$ \\
\hline B- & $=$ & 0 & $0 \%$ & B- & $=$ & 3 & $7,70 \%$ \\
\hline $\mathrm{C}+$ & $=$ & 0 & $0 \%$ & $\mathrm{C}+$ & $=$ & 2 & $5,13 \%$ \\
\hline $\mathrm{C}$ & $=$ & 2 & $5,13 \%$ & $\mathrm{C}$ & $=$ & 6 & $15,40 \%$ \\
\hline $\mathrm{C}-$ & $=$ & 0 & $0 \%$ & $\mathrm{C}-$ & $=$ & 0 & $0 \%$ \\
\hline $\mathrm{D}$ & $=$ & 1 & $2,56 \%$ & $\mathrm{D}$ & $=$ & 0 & $0 \%$ \\
\hline $\mathrm{E}$ & $=$ & 0 & $0 \%$ & $\mathrm{E}$ & $=$ & 4 & $10,30 \%$ \\
\hline Tota & & 39 & $100 \%$ & & & 33 & $100 \%$ \\
\hline
\end{tabular}

Dari Tabel 8. dapat dilihat bahwa terjadi peningkatan prestasi mahasiswa, pada mahasiswa angkatan 2015 terdapat 4 orang mahasiswa memperoleh nilai E. Sedangkan pada mahasiswa angkatan 2016 tidak ada mahasiswa yang memperoleh nilai E. Nilai rata-rata mahasiswa angkatan 2015 berada di rentang nilai E hingga A, sedangkan nilai mahasiswa angkatan 2016 berada di rentang nilai D hingga A. Sehingga dapat dikatakan bahwa metode pembelajaran kooperatif tipe STAD mampu meningkatkan pemahaman mahasiswa terhadap materi kuliah yang diberikan.

\section{Kesimpulan}

Berdasarkan analisis data dan uraian pembahasan maka dapat disimpulkan bahwa.

1. Keaktifan mahasiswa pada mata kuliah Proses Pantai melalui penerapan metode pembelajaran kooperatif tipe STAD mengalami peningkatan, ditunjukkan dengan persentase skor keaktifan mahasiswa selama perkuliahan sebesar $91,56 \%$ atau tingkat keaktifan sangat tinggi.

2. Respon mahasiswa terhadap mata kuliah Proses Pantai melalui penerapan metode pembelajaran kooperatif tipe STAD sangat tinggi, ditunjukkan dengan presentase respon mahasiswa sebesar $97,29 \%$ atau tingkat respon sangat tinggi.

3. Prestasi belajar mahasiswa pada mata kuliah Proses Pantai melalui penerapan metode pembelajaran kooperatif tipe STAD mengalami peningkatan, yang mana hal tersebut ditunjukkan pada hasil perbandingan nilai akhir mahasiswa angkatan 2015 (tanpa metode) dan mahasiswa angkatan 2016 (dengan metode).

\section{Ucapan Terima Kasih}

Terima kasih penulis sampaikan kepada Kepala Departemen Teknik Kelautan yang telah memberi ijin kepada penulis untuk melaksanakan penerapan metode pembelajaran ini terhadap mahasiswa mata kuliah Proses Pantai, juga kepada para mahasiswa mata kuliah Proses Pantai di Departemen Teknik Kelautan, Fakultas Teknik Unhas. 
Jurnal Tepat (Teknologi Terapan Untuk Pengabdian Masyarakat), Volume 1, Nomor 1, Tahun 2018

\section{Daftar Pustaka}

Dalyono. (2005). Psikologi Pendidikan, Jakarta, Rineka Cipta

Ismail. (2003). Model Pembelajaran Kooperatif, Dit.PLP Dikdasmen

M. User Usman. (2002). Menjadi Guru Professional. Bandung, Remaja Rosdakarya

M. Nur. (2005). Pembelajaran Kooperatif. Dirjen Dikti Depdiknas

R. Wiriatmadja. (2005). Metode Penelitian Tindakan Kelas. Bandung, Remaja Rosdakarya

Sugiyono. (2001). Metode Penelitian Administrasi, Bandung, Alfabeta

W. Sanjaya. (2007). Strategi Pembelajaran Kooperatif Berorientasi Standar Proses Pendidikan, Jakarta, Kencana Prenada Media Group. 